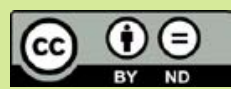

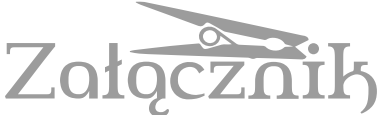

Załącznik Kulturoznawczy 3/2016

TEMAT NUMERU: KICZ NASZ WSPÓLCZESNY

\section{ŻYCIE JAKO KICZ. \\ UWAGI O SZTUCE BIOLOGICZNEJ}

MARTA MIKOŁAJEWSKA

Wydział Filologii Polskiej i Klasycznej Uniwersytetu im. Adama Mickiewicza w Poznaniu

Faculty of Polish and Clasical Philology, Adam Mickiewicz

University in Poznań (Poland)

marta.heberle@gmail.com

\section{SZTUKA BIOLOGICZNA A KICZ}

Sztuka biologiczna, w języku angielskim określana jako bio art, istnieje mniej więcej od końca lat 80. Początkowo identyfikowano ją głównie z tak zwaną sztuką genetyczną, która sprowadzała się do wizualizacji DNA za pomocą tradycyjnych technik, takich jak malarstwo czy grafika oraz obrazów wykonanych poprzez zastosowanie algorytmów genetycznych i programowania genetycznego. Stopniowo jednak artyści zaczęli włączać do warsztatu środków wyrazu narzędzia właściwe biologii molekularnej i inżynierii genetycznej. Z czasem większą uwagę zwracano nie na oprogramowanie komputerowe, a na tworzenie fizykalnych obiektów biologicznych: zmodyfikowanych genetycznie komórek, szczepów bakterii, tkanek czy złożonych organizmów. Z tego typu działalnością sztuka biologiczna identyfikowana jest obecnie - z adaptowaniem rozwiązań oferowanych przez nauki biotechnologiczne w celu tworzenia żywych dzieł sztuki. Wokół tych działań toczy się dyskusja, w której dominują głosy podkreślające wagę tego typu eksperymentów dla fundamentalnych ustaleń dotyczących tego, czym jest życie, ale także dla zrozumienia, jaki jest status tych nieistniejących dotąd w naturze, skonstruowanych przy użyciu technologii bytów. Posthumanistyczne dyskursy, takie jak estetyka troski, estetyka nieantropocentryczna czy postulowana przez Monikę Bakke „zoe-estetyka”, stanowią

1 M. Bakke, Bio transfiguracje. Sztuka i estetyka posthumanizmu, Poznań 2012. 
tylko kilka z przykładów tego rodzaju refleksji. W jakim jednak sensie podstawą dla tego rodzaju dyskusji mogą stać się prace, które w gruncie rzeczy sprowadzają się do zakresu znaczeniowego pojęcia 'kicz'? Wydawałoby się, że z chwilą wejścia do specjalistycznych laboratoriów i wykorzystania specyficznych technologii w procesie kreacji, artyści dysponują wszelkimi środkami, by problematyzować fenomen życia, kwestie związane z jego manipulacją czy patentowaniem przez duże koncerny kodów genetycznych. W jakim jednak stopniu podejmują tego rodzaju problematykę prace, w których stykamy się z kolorowymi motylami, ornamentacyjnymi kwiatami czy fluorescencyjnym królikiem? Clement Greenberg pisał o kiczu, że ,jest on mechaniczny i operuje formułami. Jest zastępczym doświadczeniem i fałszywym przeżyciem. Zmienia się zależnie od stylu, ale pozostaje zawsze tym samym. Jest wyrazem tego wszystkiego, co w naszym życiu nieautentyczne"2. Skoro kicz reprezentuje to, co w naszym życiu nieautentyczne, czy możemy posługiwać się nim, tworząc ogólne stwierdzenia dotyczące podstaw życia? Czy kiczowate artefakty mogą stanowić punkt wyjścia do poważnej dyskusji o kwestiach fundamentalnych? Czy żywe obiekty, nierzadko przywodzące na myśl wytworzone przez kulturę popularną fantazmaty i produkty, mogą powiedzieć nam coś o życiu? Co o życiu mówi nam sztuka, która na pierwszy rzut oka stanowi jedynie przejaw złego gustu? Co o życiu mówi nam kicz? Zanim zastanowimy się nad tymi pytaniami, ustalmy zakres znaczeniowy tego pojęcia.

\section{CZYM JEST KICZ?}

Badacze są w większości zgodni co do tego, że słowo 'kicz' pochodzi od niemieckiego sformułowania etwas verkitschen, co oznacza „sprzedać coś tanio" ${ }^{3}$. Określenie to związane jest z sądem estetycznym i kategorią smaku, jednocześnie ma wyraźne zabarwienie pejoratywne czy raczej negatywnie wartościujące. Kicz odnosi się do produktu kulturowego spreparowanego, aby schlebiać gustom mas. Oznacza „sztukę, która jest radosna

2 C. Greenberg, Obrona modernizmu. Wybór esejów, tłum. G. Dziamski, M. Śpik-Dziamska, Kraków 2006, s. 9.

3 T. Kulka, Kitsch, „British Journal of Aesthetics” 1988, t. 28, nr 1. 
i która jednocześnie stanowi wyraz złego smaku”4. Paul Maltby uważa, że kicz jest „kontrowersyjnym i problematycznym konceptem. Po pierwsze, jest z konieczności krytyczny: dzieło sztuki rozpoznane jako kicz zostaje natychmiast zdewaluowane, gust jego wielbicieli zdyskredytowany i wyśmiany. Po drugie, koncept ten jest wykluczający i dyskryminujący: jako etykieta kicz często stygmatyzuje sztukę, która nie wpisuje się w kanon estetyczny ustalony przez elitarnych arbitrów smaku"'. Maltby zauważa też jednak, że kicz stanowi kategorię przydatną w tym sensie, że łatwo dzięki niej rozpoznać sztukę przeznaczoną do konsumpcji, która „zapewnia bezrefleksyjną rozrywkę i niezakłóconą przyjemność"6. Tomas Kulka wskazuje, że „kicz nie jest wyłącznie artystyczną porażką - pracą, która nie wyszła. Jest w tym zjawisku coś specjalnego, co oddziela je od reszty złej sztuki"7. Na czym polega ta wyjątkowość kiczu? Czy chodzi o pewnego rodzaju formatowanie zjawisk artystycznych do statusu produktów przeznaczonych do konsumpcji? Przyjęło się, że kicz jest zjawiskiem, które wyłoniło się w XIX wieku wraz z kształtowaniem się społeczeństwa masowego. Istotną rolę $\mathrm{w}$ powstawaniu produktów, które określić można tym mianem, odegrał wzrost czasu wolnego. Wśród społeczeństw masowych pojawiła się wtedy potrzeba uczestnictwa w kulturze zapewniającej łatwą rozrywkę, niewymagającą wykształcenia ani szczególnych kompetencji odbiorczych. Clement Greenberg uważał kicz za produkt rewolucji przemysłowej i za efekt osiedlania się w miastach ogromnej liczby ludności wiejskiej w charakterze proletariatu i drobnej burżuazji. „Kultura ersatzu” miała odpowiadać potrzebom konsumpcyjnym mas, które nie były w stanie zrozumieć kultury miejskiej, a jednocześnie utraciły zainteresowanie kulturą ludową wywodzącą się z miejsca ich pochodzenia. Umacnianie się kultury masowej, czyli kiczu, oraz wycofanie się elit rządzących z poparcia dla działań awangardy

4 D. Riout, Kitsch, [w:] Dictionary of Untranslatables: A Philosophical Lexicon, ed. B. Cassin, Princeton 2014, s. 538.

5 P. Maltby, Kinkade, Koons, Kitsch, http://www.jcrt.org/archives/12.1/maltby. pdf [data dostępu: 13.03.15].
6 Ibidem.
7 T. Kulka, op. cit.
8 C. Greenberg, op. cit., s. 9. 
stanowiły dla Greenberga zapowiedź upadku kultury kształtującej wrażliwość, refleksję i dobry smak.

Podobnie rozumiał zjawisko kiczu Hermann Broch. Uważał, że kicz stanowi przejaw „radykalnego zła”, które prowadzi do zniszczenia systemu wartości. Siła kiczu polega jego zdaniem na „pomieszaniu kategorii etycznej z estetyczną"10. Kicz według Brocha ma za zadanie zapewnić niewymagającą wysiłku intelektualnego i zaangażowania odbiorcy przyjemność. Jako taki nie może stanowić tworzywa dobrego dzieła sztuki; dzieła wielopoziomowego, którego forma odsyła do istotnego problemu. Kicz stał się też przedmiotem krytyki Waltera Benjamina, który całkowicie wyłączał to zjawisko z obszaru sztuki. Postrzegając go jako fenomen odrębny, który jest czymś innym niż działalność artystyczna, negował tym samym możliwość istnienia „kiczowatej sztuki”. Według ustaleń Winifred Menninghaus, badaczki zajmującej się tą problematyką w pismach niemieckiego filozofa, kicz stanowił dla Benjamina praktyczny (w przeciwieństwie do „bezinteresowności” sztuki) przedmiot, który sprawia, że brak jest krytycznego dystansu między nim a obserwatorem: „kicz oferuje natychmiastową emocjonalną gratyfikację bez wysiłku intelektualnego, bez dystansu i bez sublimacji"ll. Warto w tym miejscu zauważyć, że tego rodzaju opinie i uwagi dotyczące kiczu były wśród teoretyków popularne mniej więcej do lat 50. XX wieku. Później w artystycznym świecie wyłoniły się tendencje, które odmieniły kicz i jego postrzeganie przez krytyków. Denys Riout uważa, że kicz zmienił się za sprawą pop artu, który doprowadził do dalszego rozmycia wartości ustanowionych przez awangardę, oraz za sprawą tak zwanego „kampu”, stanowiącego rodzaj estetyki promującej jako zabawne to, co jest w złym guście. Riout wskazuje, że od tej pory artyści nie tylko tworzyli prace dające się opisać za pomocą kategorii kiczu, ale celowo łączyli elementy wywołujące

9 H. Broch, Evil in the Value System of Art, [w:] idem, Geist and Zeitgeist: the Spirit in an Unspiritual Age: Six Essays, ed. and trans. by J. Hargraves, New York 2002, s. 195 (jeśli nie zaznaczono inaczej, tłumaczenia pochodzą od autorki artykułu).

10 Ibidem.

11 W. Menninghaus, On the 'Vital Significance' of Kitsch: Walter Benjamin's Politics of 'Bad Taste', [w:] Walter Benjamin and the Architecture of Modernity, ed. A. Benjamin, Ch. Rice, Melbourne 2009, s. 41. 
u odbiorcy przyjemność estetyczną z wątkami wywrotowymi ${ }^{12}$. Tym samym kicz zmienił swoje oblicze. Nie był postrzegany wyłącznie jako przejaw złego gustu, ale też jako celowe wykorzystanie motywu utożsamianego ze złym gustem, stanowiące jednocześnie punkt wyjścia do analizy złożonych problemów i wnikliwości krytycznej. Tego rodzaju działalność polegającą na świadomym i celowym operowaniu kiczem Maria Poprzęcka określa jako postkicz ${ }^{13}$. Prace mieszczące się w jego obrębie mogą być atrakcyjne dla szerokiej publiczności: zarówno dla widza, który dostrzega tylko wierzchnią warstwę projektu, aspekt wizualnej, przynoszącej przyjemność tandety, jak i dla widza wykształconego, który za fasadą blichtru rozpoznaje inne sensy i znaczenia.

\section{FLUORESCENCYJNY KRÓLIK}

Powróćmy do pytania postawionego na początku tych rozważań: czy podstawą dla dyskusji dotyczącej życia może być projekt, który wpisuje się w zakres znaczeniowy pojęcia 'kicz'? Postaramy się na nie odpowiedzieć, rozważając przypadek najbardziej, jak sądzę, emblematyczny dla sztuki biologicznej - fluorescencyjnego królika o imieniu Alba. GFP Bunny autorstwa Eduarda Kaca stanowi przykład sztuki transgenicznej - pewnej tendencji wyróżnionej przez artystę w obrębie bio artu. Jak wskazuje sam twórca: „jest to nowa forma sztuki, której podstawę stanowi wykorzystanie technik inżynierii genetycznej, pozwalających na wprowadzanie do organizmu genów syntetycznych bądź występujących naturalnie $\mathrm{z}$ jednego gatunku do drugiego w celu tworzenia unikalnych żywych istot"14. Alba przyszła na świat w 2000 roku. Powołanie jej do życia wymagało ścisłej współpracy artysty $z$ naukowcami pracującymi dla Instytutu INRA (Institut National de la Recherche Agronomique) w Jouy-en-Josas we Francji. Spośród wielu jednostek naukowych zdolnych w tamtym okresie do przeprowadzenia tego typu działania tylko ta zgodziła się pomóc w realizacji zamysłu przedstawionego przez artystę. Proces kreacji transgenicznego zwierzęcia polegał na bezpośredniej ingerencji w genom. W wyniku tej operacji do życia powołana została hybrydyczna istota - królik albinos, do którego zygoty wszczepiono

12 D. Riout, op. cit., s. 539.

13 M. Poprzęcka, O złej sztuce, Warszawa 1998.

14 E. Kac, Transgenic Art, „Leonardo Electronic Almanac” 1998, t. 6, nr 11. 
syntetyczną mutację genu fluorescencji, naturalnie występującego u meduz gatunku Aequorea victoria. Alba, będąca podwójnym mutantem ${ }^{15}$, pozornie niczym nie różni się od innych pozbawionych pigmentu królików, jednak w odpowiednich warunkach - po naświetleniu promieniami o określonej częstotliwości - emituje intensywne jasnozielone światło. Gdyby ostatecznym celem projektu było stworzenie uroczego udomowionego miniaturowego królika, emitującego dodatkowo zieloną poświatę niczym w baśniach, projekt można by uznać za apoteozę kiczu. Jak jednak wskazuje artysta, kreacja nowej istoty na drodze genetycznych modyfikacji była jedynie punktem wyjścia tego procesualnego przedsięwzięcia. Kac zauważa, że jego dzieło „obejmuje stworzenie zielonego, fluorescencyjnego królika, publiczny dialog wywołany przez projekt, a także integrację zwierzęcia ze środowiskiem społecznym"16. Druga część projektu rozpoczęła się z chwilą upublicznienia wiadomości o przyjściu stworzenia na świat. Obejmowała wszelkie związane z kreacją Alby reakcje: publiczną debatę, otwarty sprzeciw przeciwko tego typu praktykom, kontrowersje, a także konsekwencje w postaci ocenzurowania projektu przez ówczesnego dyrektora Instytutu INRA, który odmówił wydania fluorescencyjnego gryzonia z laboratorium. Ostatnie wydarzenie pchnęło drugą fazę projektu w nieoczekiwanym kierunku, skutkując protestami obrońców artystycznych poczynań pioniera bio artu, a także odwlekając w czasie końcowe stadium projektu, które zakładało przeniesienie zwierzęcia do posiadłości jego twórcy, zintegrowanie go z nowym otoczeniem, doświadczanie codziennych interakcji z nim i, przede wszystkim, otoczenie go odpowiedzialną opieką. Na uwagę zasługuje fakt, że GFP Bunny nigdy nie został pokazany publicznie. Transgenicznego królika przetransportowano ostatecznie do domu twórcy, jednak nigdy nie został on wystawiony w obiegu galeryjnym jako żywy artefakt. Strategia wystawiennicza projektu obejmowała prezentację zdjęć, plakatów, dokumentacji prac laboratoryjnych, a także publiczne debaty i dyskusje, które ostatecznie toczyły się pod nieobecność Alby.

15 Alba nie jest jedynie efektem modyfikacji polegającej na wszczepieniu do zygoty królika genu fluorescencji, gdyż już same króliki albinosy to recesywna naturalna mutacja, celowo rozmnażana przez ludzi.

16 E. Kac, GFP Bunny, „Leonardo” 2003, nr 36, s. 97. 
Chciałabym w tym miejscu przyjrzeć się argumentom, których używali przeciwnicy i krytycy projektu, licząc na to, że pozwolą nam one ustalić, na czym polega i w jaki sposób manifestuje się kicz w projekcie Kaca.

Jednym z powodów ostrej krytyki wymierzonej w pracę była jej rzekoma „dekadenckość”, objawiająca się w nadaniu białemu królikowi zdolności całkowicie zbędnej, właściwej pewnemu gatunkowi meduz, w przypadku których występowanie tego rodzaju białka jest funkcjonalnie uzasadnione. Praca Brazylijczyka została tym samym sprowadzona do poziomu pozbawionego znaczeń, atrakcyjnego wizualnie gadżetu, do poziomu powierzchni i fasadowości, oraz uznana za niesmaczny eksperyment, wykorzystujący, co gorsza, istotę żywą do realizacji niegodnego, niskiego celu. Steve Tomasula, podejmując tę kwestię i jednocześnie nawiązując do innych prac, u podstawy których leżą działania na genach, z ironią przedstawia kolejny aspekt związany z domniemaną bezużytecznością takich przedsięwzięć z perspektywy badań naukowych: „Alba, podobnie jak Venus Davisa ${ }^{17}$ czy każda inna praca należąca do nurtu sztuki genetycznej, nie zostanie wykorzystana w badaniach nad rakiem czy innymi medycznymi przypadkami. I jako że prace te są »bezużyteczne«, są postrzegane jako »dekadenckie«, tak dekadenckie jak ornament, na przykład niepragmatyczne złote rybki i kwiaty zniszczone przez Czerwoną Gwardię w trakcie Rewolucji Kulturalnej Mao"'18. Zakładając, że

17 Tomasula pisze tutaj o projekcie autorstwa Joego Davisa, który także wpisuje się w paradygmat sztuki biologicznej. Microvenus to prosty symbol graficzny przypominający skrzyżowanie liter „Y” oraz „I”. Jest to germański znak runiczny symbolizujący życie, a także schematycznie zarysowane żeńskie genitalia. Projekt Davisa zakładał umieszczenie owego znaku w genomie bakterii, powielenie go w efekcie rozmnażania drobnoustrojów, a następnie wysłanie w kosmos, by znak ludzkiej inteligencji dotarł do istot pozaziemskich. Realizacja tego zamierzenia wiązała się z przetłumaczeniem informacji graficznej na informację biologiczną; najpierw run został zcyfryzowany, a następnie przetłumaczony na łańcuch dwudziestu ośmiu nukleotydów DNA. Syntetyczne molekuły z zakodowaną informacją zostały umieszczone w bakteriach $E$. coli, szczepie odpowiedzialnym za prawidłowe trawienie, wykorzystywanym w badaniach NASA ze względu na odporność na ekstremalne warunki. Bakterie szybko rozmnożyły się w laboratoryjnej zlewce; powstały miliony komórek, z których każda zawierała identyczny obraz Microvenus.

18 S. Tomasula, Genetic Art and the Aesthetics of Biology, „Leonardo” 2002, nr 35, s. 143. 
autor tych słów nie jest zwolennikiem rządów komunistycznego dyktatora, możemy odczuć, że zarzut dotyczący bezużyteczności wydaje mu się absurdalny i wynikający z ignorancji, z komentowania pracy wyabstrahowanej z szerszego, wyłożonego przez artystę kontekstu, wreszcie $z$ banalizowania poruszanych przez nią problemów i ograniczenia jej do nieadekwatnej definicji objet d'art, według której istotą i ostatecznym celem działań Kaca była kreacja fluorescencyjnej maskotki - zbytecznego ornamentu.

Jak wiemy, narodziny Alby były jedynie punktem wyjścia projektu, natomiast Kac w zaproponowanej koncepcji sztuki transgenicznej stanowczo odcina się od tworzenia skończonych artefaktów, które nie mają potencjału rozwoju: „Z racji tego, że jestem artystą transgenicznym, interesuje mnie nie tyle kreowanie genetycznych przedmiotów, ile raczej tworzenie społecznych podmiotów. Innymi słowy, za istotny uważam całkowicie zintegrowany proces tworzenia królika, wprowadzenia go w społeczeństwo i zapewnienia mu kochającego i opiekuńczego środowiska, w którym będzie mógł rosnąć zdrowo i bezpiecznie"19. Kac liczy na wypracowanie estetyki podkreślającej społeczne, a nie formalne aspekty życia. Stworzenie fluorescencyjnej istoty ma być początkiem długiego procesu inicjującego debatę dotyczącą granic manipulacji genetycznych, sztuki, dobrego smaku. Zielony królik nie ma być wartością samą w sobie, dziwacznym, skończonym artefaktem, lecz inspiracją do namysłu nad innością, nad etyką artystyczną, nad stosunkiem odbiorców do genetycznie modyfikowanych organizmów. Wielokrotnie podkreślana jest też przez artystę konieczność otoczenia tych wyjątkowych istot szczególną opieką, zintegrowania ich z innymi, niezmodyfikowanymi stworzeniami. Mimo tej artystycznej eksplikacji projektu pojawiło się wiele głosów krytycznych, wskazujących, że jest on „ornamentacyjny”, a przez to powierzchowny - trudno doszukiwać się sensów i znaczeń zamierzonych przez artystę pod warstwą popkulturowej, lukrowanej dekoracyjności.

Kwestię powracającej w najnowszych praktykach artystycznych ornamentacyjności w interesujący sposób rozwinął Gunalan Nadarajan, jednocześnie zręcznie broniąc „fluorescencyjnego królika”. Nadarajan zgadza się co prawda z tym, że obecnie obserwujemy w sztuce - szczególnie tej, która wykorzystuje biotechnologiczne manipulacje - zwrot w kierunku

19 E. Kac, GFP..., op. cit., s. 98. 
ornamentu, dekoracyjności, zauważa jednak także, że jest to swego rodzaju działanie subwersywne. Wskazuje, że artyści, posługując się tymi samymi metodami, które stosuje się w „biotechnologii ornamentacyjnej” ${ }^{20}$, czyli „badaniu, manipulowaniu i konstruowaniu form życia dla celów ornamentacyjnych"21, dostarczają krytycznej oceny tych procesów. Nadarajan powołuje specjalną kategorię „estetyki parergonalnej”22 (parergonal aesthetics), w przypadku której „ornament służy destabilizacji takich pojęć jak celowość czy funkcjonalność w odniesieniu do żywych istot" ${ }^{23}$. Choć GFP Bunny stanowi w jego odczuciu fenomen czysto ornamentalny, nie jest to w żadnym razie równoznaczne $z$ ubóstwem znaczeniowym pracy: „Fascynujące jest rozpatrywanie rozległych zamierzeń i implikacji pracy, podczas gdy najbardziej oczywistym jej aspektem jest fluorescencja - cecha ornamentalna"24.

Estetyka parergonalna zawiesza hierarchizowanie i podział aspektów życiowych na ważniejsze i mniej ważne, na te, które usprawiedliwiają biotechnologiczne dociekania (np. rozwiązania dotyczące ludzkiego zdrowia), oraz te, które takiego potencjału nie posiadają (skonstruowanie pięknego stworzenia). „Dlaczego zatem psy nie są niebieskie w czerwone kropki, a konie nie promieniują fosforyzującymi kolorami na nocnych łąkach?”25 pyta Vilem Flusser. Nadarajan odpowiedziałby prawdopodobnie, że jest tak dlatego, iż ornament przestał być pusty i jałowy, kiedy stał się wykorzystywanym $\mathrm{z}$ rozmysłem narzędziem krytyki, które zdolne jest wywołać - kazus Alby - debatę poruszającą zasadnicze kwestie.

Docieramy tutaj do momentu, w którym nasze rozważania przybierają paradoksalny kierunek. Okazuje się bowiem, że z głosów krytycznych, z zarzutów o dekadenckość, bezużyteczność i stosowanie pustych znaczeniowo ornamentów grupa teoretyków wyprowadza linię obrony projektu, który dotyczy jednak istotnych kwestii, takich jak status genetycznie modyfikowanych organizmów, ich integracja ze środowiskiem i światem ludzi oraz

20 G. Nadarajan, Ornamental Biotechnology and Parergonal Aesthetics, [w:] Signs of life. Bio Art and Beyond, ed. E. Kac, Cambridge 2007, s. 43.

${ }^{21}$ Ibidem.

22 Ibidem.

${ }^{23}$ Ibidem, s. 51.

${ }^{24}$ Ibidem, s. 52.

25 V. Flusser, Curie's Children, „Artforum” 1988, nr 27, s. 9. 
etyka artystyczna. Dlatego też, gdybyśmy zdecydowali się opisać projekt GFP Bunny za pomocą kategorii kiczu, skłanialibyśmy się bardziej w stronę rozumienia proponowanego przez Riouta i Poprzęcką. W tym świetle decyzja Kaca o stworzeniu fluorescencyjnego „pupila” byłaby działaniem w pełni świadomym i celowym, mającym na celu zainteresowanie dużej grupy odbiorców - niekoniecznie wykształconych w odbiorze sztuki - nie tylko samym stworzeniem, lecz także problematyką dotyczącą istot transgenicznych. Za takim widzeniem pracy przemawiałby też fakt rezygnacji Kaca $z$ prezentowania stworzenia publicznie w przestrzeni galeryjnej, gdzie mogłoby być narażone na stres związany $\mathrm{z}$ obecnością odwiedzających. Być może Alba, której nie widział nikt prócz artysty, jego rodziny oraz personelu francuskiego laboratorium odpowiedzialnego za jej powstanie, faktycznie miała być poważnym projektem świadczącym o odpowiedzialności naukowców, artystów i o możliwościach związanych z wykorzystaniem biotechnologii?

Takie wnioski na temat projektu można wyciągnąć na podstawie głosów jego obrońców, odpowiadających na zarzuty dotyczące „dekadenckości”, ornamentacyjności i bezużyteczności. Zastanówmy się jednak nad tym, z jakim obrazem biotechnologii konfrontuje odbiorców GFP Bunny.

Bez wątpienia serie wykładów, warsztatów i publicznych dyskusji, które składały się na strategię wystawienniczą pracy, można uznać za społecznie użyteczne. Stworzenie uroczego transgenicznego „pupila” oswaja ludzi z inżynierią genetyczną, biologią molekularną i innymi gałęziami technologii biologicznych, postrzeganych zazwyczaj jako dziedziny hermetyczne, posługujące się trudnym żargonem zrozumiałym wyłącznie dla osób bezpośrednio w nie zaangażowanych. Powstaje przestrzeń do dialogu dotyczącego badań i eksperymentów prowadzonych obecnie na dużą skalę, które nie są w pełni jasne, zrozumiałe i oczywiste, a przez to często stanowią podstawę do powielania mitów, uprzedzeń i fałszywych przeświadczeń. Należy jednak zauważyć, że wizerunek biotechnologii oferowany przez projekt jest utopijną wizją nieskończonych możliwości. Przeciętny Kowalski dowiaduje, że w tym momencie ludzkość posiada nieograniczone możliwości manipulowania naturą i że konsekwencją tego rodzaju manipulacji mogą być urokliwe zwierzęta domowe, u których na skutek ingerencji w genom nie wystąpiły powikłania, choroby czy inne obniżające jakość życia zwierzęcia skutki. Zdjęcia i postery przedstawiające wielokrotnie powielony obraz radośnie 
skaczącego zielonego królika nie mówią nic o zagrożeniach płynących z zastosowania technologii biologicznych, nieudanych eksperymentach, laboratoryjnych aberracjach i cierpieniu istot, $\mathrm{u}$ których $\mathrm{w}$ wyniku ingerencji w genom wystąpiły poważne mutacje wykluczające normalną egzystencję. Artysta nie odnosi się też do innej istotnej kwestii. Ingerując w genom na poziomie molekularnym, nigdy nie można przewidzieć do końca, jaka będzie ostateczna ekspresja modyfikacji w złożonym organizmie. Kac twierdzi, że „zdecydował się przystąpić do projektu, ponieważ stało się jasne, że jest to bezpieczne"26. Skąd jednak mógł mieć taką pewność? Jeśli podstawą takiego przeświadczenia były wcześniejsze manipulacje na genomach innych żywych istot, być może należało odnieść się do tych eksperymentów, ich wyników i konsekwencji, nawet gdyby miało to prowadzić do ujawnienia potencjalnych niebezpieczeństw wiążących się z tego typu działaniami i nieprawidłowości stanowiących ich efekt? Pamiętajmy też, że króliki, obok szczurów i myszy, są popularnymi zwierzętami doświadczalnymi, na których testuje się produkty farmaceutyczne, w tym terapie genowe, kosmetyki oraz inne komponenty chemiczne docelowo przeznaczone dla ludzi.

Czy fluorescencyjny królik mówi nam coś o tych kwestiach? Czy dowiadujemy się, co dzieje się za zamkniętymi drzwiami placówek badawczych i specjalistycznych laboratoriów? Czy projekt podejmuje refleksję na temat losu żywych testerów, który naznaczony jest bólem i strachem? Niestety, w przypadku tego projektu zatrzymujemy się na konkluzji, że zwierzęta laboratoryjne mają się świetnie, modyfikacje na ich genach przynoszą spektakularny pod względem wizualnym efekt, a one same żyją długo, otoczone opieką ze strony odpowiedzialnych naukowców.

Pomijanie wymienionych wyżej kwestii i jednocześnie promowanie dzieła jako projektu dotyczącego odpowiedzialności zakrawa na hipokryzję, a w najlepszym wypadku na całkowity brak świadomości dotyczącej realiów współczesnych badań naukowych z dziedziny biologii. Zignorowany został też fakt patentowania genomów żywych istot, szczególnie tych posiadających potencjał rynkowy; istot, których utowarowienie może wiązać się pokaźnymi profitami finansowymi. Chodzi tu właśnie przede wszystkim o zwierzęta, które tak jak zielony królik nadają się do hodowli domowej. Kac

26 E. Kac, GFP..., op. cit., s. 100. 
zrealizował swój słynny projekt rok po tym, jak naukowcy z Narodowego Uniwersytetu Singapuru opatentowali popularny gatunek rybek akwariowych zmodyfikowanych o gen fluorescencji, który sprawia, że emitują one, podobnie jak Alba, jasnozielone światło. Naukowcy podpisali następnie kontrakt z dużą firmą Yorktown Technologies, przekazując prawa do produkcji i sprzedaży genetycznie zmodyfikowanych ryb. W 2003 roku gatunek pod nazwą GloFish trafił do sklepów zoologicznych w Stanach Zjednoczonych. Autor GFP Bunny milczy w sprawie patentowania życia, implikacji etycznych tego rodzaju działań; ignoruje też całkowicie kontekst rynkowego obiegu tego rodzaju istot oraz problem komodyfikacji życia. W związku z tym, pracę - wbrew temu, co sugerują jej obrońcy - można postrzegać jako nieuzasadnioną manipulację na genomie, dążącą do wizualnego efekciarstwa, spowitą dodatkowo idealistyczną i bezkrytyczną opowiastką o cudach biotechnologii. Tym samym można ją uznać kicz. Co więcej, prezentowane $\mathrm{w}$ przestrzeni galeryjnej plakaty i zdjęcia królika w połączeniu $\mathrm{z}$ afirmatywnym i naiwnym traktowaniem metod, które umożliwiły realizację projektu, można w gruncie rzeczy potraktować jako swoistą reklamę możliwości oferowanych przez biotechnologię.

Kac uważa, że zależało mu na stworzeniu fluorescencyjnego królika nie jako produktu końcowego, ale na zainicjowaniu w ten sposób debaty dotyczącej istotnych kwestii. Niestety, zbanalizowanie debaty dotyczącej technik biologicznych i zignorowanie szerokich konsekwencji ich rozprzestrzeniania popycha projekt bardziej w kierunku produktu końcowego, do tego w wątpliwym guście.

Warto w tym miejscu przywołać zdanie George'a Gesserta, jednego z przedstawicieli nurtu sztuki biologicznej. Gessert odwraca porządek słowa 'kicz', twierdząc (w podobnym duchu do przywołanego wcześniej Waltera Benjamina), że nie jest to kategoria opisująca wytwory artystyczne, ale właśnie produkty rynkowe. Jako artysta pracujący podobnymi do Kaca technikami i krzyżujący różne gatunki roślin kwitnących, Gessert krytykuje masową produkcję genetycznie zmodyfikowanych kwiatów, nazywając je kiczowatymi ${ }^{27}$. Uważa, że zarzuty dotyczące braku odpowiedzialności u artystów pracujących w obszarze bio artu są absurdalne, ponieważ według

${ }^{27}$ G. Gessert, Green Light: Toward an Art of Evolution, Cambridge 2010, s. 81. 
niego to kicz - pod postacią towarów rynkowych - powoduje moralną obojętność. Nawet jeśli Gessert ma rację, projekt Kaca i tak został niestety sformatowany niczym spektakularny biotechnologiczny... produkt, osnuty dodatkowo całkowicie nieprzekonującą w moim odczuciu opowieścią o trosce i odpowiedzialności.

Powróćmy jeszcze do zapowiadanego na początku tego tekstu pytania: cóż ważnego o życiu może nam powiedzieć praca zaklasyfikowana jako kicz? Zanim podejmę próbę odpowiedzi na to pytanie, chciałabym doprecyzować, co dokładnie mam na myśli, posługując się pojęciem 'życie’. Liczę, że tego rodzaju komentarz wyjaśni i usprawiedliwi moją krytykę i negatywne wartościowanie twórczości brazylijskiego artysty. Moja refleksja nad znaczeniem fenomenu życia rozpoczyna się od kwestii fundamentalnej, to znaczy od poszukiwania jego definicji. Już na tym etapie napotykamy jednak zasadniczy problem. Okazuje się bowiem, że jedna, spójna i logiczna definicja tego zjawiska - wspólna i prawdziwa dla pewnej klasy obiektów i pozwalająca na rozgraniczenie materii ożywionej od nieożywionej - po prostu nie istnieje. Próbę wyjaśnienia zjawiska życia podjęły niemal wszystkie dziedziny naukowe, począwszy od biologii, poprzez fizykę i chemię, aż po nauki humanistyczne. Sposobu na formalną definicję życia poszukiwali także matematycy. Problematyce bytu i istnienia poświęcony jest potężny dział filozofii - ontologia. Wszystkie te dziedziny wypracowały własne rozumienie życia, eksponujące inne jego właściwości i cechy. Proliferacja definicji prowadzi jednak w konsekwencji do dezorientacji: koncepcje często wzajemnie się wykluczają, niektóre są wewnętrznie sprzeczne, a mnogość konstruktów myślowych wyklucza możliwość jednoznacznego rozstrzygnięcia, czy w danej instancji mamy do czynienia z życiem, czy nie. Edward Trifonov, badacz z Instytutu Różnorodności Genetycznej w Haifie, doliczył się aż „stu dwudziestu trzech definicji tego niejasnego fenomenu”28, uznając ostatecznie wszystkie za nieprecyzyjne i niezadowalające.

W wielość dysharmonijnych definicji wpisana jest też niepokojąca możliwość, że życie ma charakter relatywny, a nie absolutny. W Czarodziejskiej górze Tomasz Mann pisał: „Czymże jest życie? Tego nie wiedziano. Jest świadome siebie, niewątpliwie, skoro tylko staje się życiem, ale nie wie,

28 E. Trifonov, Definition of Life: Navigation through Uncertainties, "Journal of Biomolecular Structure and Dynamics” 2012, vol. 29, nr 4. 
czym jest"29. Blisko sto lat po konstatacji niemieckiego pisarza stan naszej wiedzy o życiu na poziomie definicyjnym przedstawia się podobnie. Jest to o tyle niepokojące, że obecnie dysponujemy narzędziami pozwalającymi na modyfikację tego, co intuicyjnie jako życie rozpoznajemy. Nadal jednak nie jesteśmy w stanie odpowiedzieć na pytanie, czym jest życie. Dopóki nie spotkamy się z jego określonym przypadkiem, dopóki go nie „ujrzymy”, dopóty w niewytłumaczalny, irracjonalny sposób nie rozpoznamy, że oto właśnie z nim mamy do czynienia.

Przyjmowanie określonej definicji jako instancji weryfikującej prowadziło wielokrotnie do sytuacji, w których pewne zjawiska były całkowicie wykluczane ze sfery życia tylko po to, by po kilku latach, wraz z innym paradygmatem i inną definicją, odzyskać status istot żywych. Warto w tym miejscu przytoczyć przykład badań prowadzonych w 1976 roku przez bezzałogową sondę Viking, które miały na celu poszukiwanie życia pozaziemskiego. Pobrane przez lądownik próbki zostały zbadane przez pryzmat restrykcyjnej definicji metabolicznej, a pewne zaobserwowane zmiany uznano wówczas za reakcje chemiczne zachodzące w skałach. Dziś okazuje się jednak, że mogły to być przejawy aktywności żyjących na Marsie mikroorganizmów, a więc życia, co przez metaboliczną definicję zostało z gruntu wykluczone. Wygląda więc na to, że wobec bezradności definicji naukowych jesteśmy zdani na swój ogląd i przeczucie, bez względu na to, jak nienaukowe i niemetodyczne byłyby te techniki. W kwestii rozstrzygania, co życiem jest, a co nie, nie dysponujemy lepszą metodą niż pozarozumowe i przedpojęciowe przeczucia.

W pracy Kaca zabrakło owego życia: unaocznionego, doświadczalnego przez zmysły. Obecność rekombinowanego genetycznie organizmu została zastąpiona plakatami i zdjęciami przedstawiającymi flurescencyjnego królika, jednak mogły one równie dobrze stanowić efekt manipulacji w programie graficznym. Odbiorca nie ma zatem możliwości rozpoznania życia w GFP Bunny, nie otrzymuje tė̇ w moim odczuciu impulsu do wkroczenia na głębszy poziom refleksji o życiu zarówno ludzkim, jak i nie-ludzkim oraz ich wzajemnych relacjach, ślizga się bowiem jedynie po powierzchni kiczowatych reprezentacji wizualnych. Faktem jest, że bezpośrednie działanie

29 T. Mann, Czarodziejska góra, t. 1, tłum. J. Kramsztyk, Warszawa 1972, s. 294. 
na genach, od którego rozpoczęła się realizacja projektu, kieruje uwagę odbiorcy w stronę przemyśleń nad tym, co stanowi biologiczną podstawę życia. Zrozumieniu tych kwestii służyły też prowadzone przez artystę wykłady i dyskusje, w czasie których objaśniano, że rolę nośnika informacji genetycznej organizmów żywych pełnią występujące w chromosomach kwasy nukleinowe. Zarówno w przypadku człowieka, jak i transgenicznego stworzenia wymykającego się kategoriom systematycznym fundament ten jest taki sam. Różnimy się jedynie konfiguracją, w jakiej rozmieszczone są poszczególne związki. Ten uniwersalny charakter budulca kodującego życie sugeruje, że w rzeczywistości jesteśmy bliżej nie tylko fluorescencyjnego królika, lecz także wszystkich innych mniej bądź bardziej złożonych stworzeń, i mimo znaczących różnic - istnieje między nami więź molekularnej materialności szyfrującej istnienie.

Ta obserwacja stanowi solidną podstawę dla dyskursów posthumanistycznych, odrzucających paradygmat antropocentryczny. Okazuje się bowiem, że człowiek nie jest gatunkiem wyizolowanym, lecz powiązanym z innymi nie-ludzkimi formami życia. Co więcej, jak wskazuje Monika Bakke: „bez nie-ludzkiej sfery nie ma tego, co tak bardzo ludzkie, jednak nie przez jej zanegowanie - jak nam się do tej pory zdawało - ale poprzez łączność i ciągłe współtworzenie" ${ }^{30}$. Skoro jednak projekt Kaca rzeczywiście miał na celu podjęcie tej problematyki, czy faktycznie niezbędne było stworzenie enigmatycznego fluorescencyjnego królika, którego nikt nigdy nie widział? Ostatecznie cała praca zyskała kształt wydarzenia o charakterze społecznym, stanowiła pewien kazus, fenomen oparty na dyskusjach i debacie. Do tego typu działań Kac nie potrzebował genetycznie zmodyfikowanego fluorescencyjnego zwierzęcia. Nie potrzebował też ani legendy, która powstała wokół niewidzianej przez nikogo publicznie istoty, ani kiczowatej otoczki tandetnych obrazków. Ten zabieg, zakrawający na mistyfikację oraz ograniczenie strony wizualnej pracy do posterów i zdjęć wątpliwego gustu, zepchnął dzieło Kaca w stronę kiczu i znacząco osłabił wydźwięk debaty, która zgodnie z zamierzeniem artysty miała na celu postawienie istotnych pytań o życie ludzkie, nie-ludzkie i ich wzajemne zależności.

30 M. Bakke, op. cit., s. 241. 
Skoro jednak Alba faktycznie powstała, należało zadbać o właściwe warunki pozwalające na jej publiczną prezentację. Wystawy z udziałem żywych, w tym też często transgenicznych zwierząt nie są nowością, nie są też, mimo pewnych trudności, niemożliwe do zorganizowania. Wystarczy w tym miejscu przywołać chociażby projekt Katy High, w którym artystka podjęła problematykę transgenicznych szczurów laboratoryjnych $\mathrm{z}$ wszczepionym ludzkim materiałem genetycznym. High odkupiła zwierzęta zapadające na typowo ludzkie choroby, zapewniła im odpowiednią opiekę i umieściła je w przestrzeni galeryjnej, zaadaptowanej w sposób przywodzący na myśl laboratorium. Odwiedzający tę specyficzną wystawę mieli szansę odczuć bezpośrednią bliskość transgenicznych zwierząt cierpiących dla dobra człowieka.

W przypadku pracy Kaca możliwość empirycznego obcowania z transgeniczną istotą pozwoliłaby odbiorcom rozpoznać w niej życie, zaś samo doświadczenie wzmocniłoby znacząco zaangażowanie w dyskusję dotyczącą związków człowieka z innymi, nie-ludzkimi formami życia. Niestety, w przypadku GFP Bunny w miejsce fluorescencyjnego królika i unikalnego doświadczenia odbiorczego publiczność otrzymała tandetną reprezentację. Mój podstawowy zarzut wobec realizacji brazylijskiego artysty dotyczy właśnie absencji tytułowego królika (zakładając, że faktycznie on powstał); zastąpienia obecności unikalnej istoty - kiczem, który zniechęca do refleksji i debaty. Jeśli zwierzę rzeczywiście zostało powołane do życia, jestem zdania, że należało pokazać je publicznie. Kwestie związane z zapewnieniem mu odpowiednich warunków podczas prezentacji stanowiłyby kolejny mocny argument $\mathrm{w}$ dyskusji nad odpowiedzialnością i opieką nad nie-ludzkimi formami życia, nad wzajemnymi relacjami ludzi i nie-ludzi.

Jeśli Kac nie planował pokazać Alby publicznie, być może w ogóle nie należało powoływać jej do życia. W obliczu tego, jak ostatecznie projekt był prezentowany, kreacja transgenicznego zwierzęcia wydaje się nieuzasadniona, całkowicie niesfunkcjonalizowana i pretekstowa, zaś sama fluorescencja jawi się jako pusty zabieg schlebiający popkulturowym trendom.

Ponadto ocena projektu nasuwa jeszcze inne niepokojące wnioski. Jeśli bowiem, jak ustaliliśmy powyżej, dzieło Kaca stanowi w swym wyrazie afirmację biotechnologii, to akceptuje tym samym jej ingerencję we wszystkie poziomy życia - w tym także ludzkiego. Skoro można zmodyfikować genetycznie królika, nie ma przeszkód, by to samo zrobić z człowiekiem - oto 
konkluzja pracy. W tym sensie projekt legitymizuje też terapie genowe, patentowanie genów oraz usprawiedliwiane koniecznością badań naukowych genetyczne profilowanie pacjentów, często bez ich wiedzy i zgody. Nie ma technologii transparentnych, które nie niosłyby za sobą określonych zmian i które pozostają bez wpływu na życie ludzi i nie-ludzi, a już z całą pewnością nie należy do nich biotechnologia.

Kac, niestety, ignoruje te kwestie, co sprawia, że nie jestem przekonana, czy zgodnie z jego zapewnieniami projekt faktycznie dotyczy troski i odpowiedzialności. Wbrew temu, co sugerują często obrońcy jego pracy, kicz nie jest tu w moim odczuciu zabiegiem pełniącym funkcje krytyczne czy demaskatorskie, wręcz przeciwnie.

Jak wspominałam wcześniej, Kac liczył na stworzenie estetyki podkreślającej społeczne, a nie formalne aspekty życia. Czy można jednak poważnie podjąć problematykę społecznych aspektów życia, ignorując całkowicie potężną technologię, która doprowadziła do jego stworzenia, jej konteksty, potencjalne skutki i niebezpieczeństwa z nią związane? Czy można poważnie zajmować się kwestiami troski, odpowiedzialności, zwracać uwagę na dyskursy posthumanistyczne zrywające z nadrzędną rolą człowieka wobec innego życia na planecie i proponować jednocześnie projekt, na podstawie którego przeciętny odbiorca dowiaduje się jedynie, że na potrzeby sztuki możemy dowolnie manipulować życiem innych istot przy pomocy nieobojętnej przecież technologii?

\section{Bibliografia}

Giorgio Agamben, Open: Man and Animal, Stanford University Press, California 2004.

Monika Bakke, Bio transfiguracje. Sztuka i estetyka posthumanizmu, Wydawnictwo Naukowe UAM, Poznań 2012.

Encountering Life in the Universe: Ethical Foundations and Social Implications of Astrobiology, ed. Ch. Impey, A.H. Spitz, V. Stoeger, University of Arizona Press, Arizona 2013.

Hermann Broch, Evil in the Value System of Art, [w:] idem, Geist and Zeitgeist: the Spirit in an Unspiritual Age: Six Essays, ed. and trans. by J. Hargraves, Suhrkamp, New York 2002.

Vilém Flusser, Curie’s Children, „Artforum” 1988, nr 27. 
George Gessert, Green Light: Toward an Art of Evolution, The MIT Press, Cambridge 2010.

Clement Greenberg, Obrona modernizmu. Wybór esejów, tłum. G. Dziamski, M. Śpik-Dziamska, Universitas, Kraków 2006.

Eduardo Kac, GFP Bunny, „Leonardo” 2003, nr 36.

Eduardo Kac, Transgenic Art, „Leonardo Electronic Almanac” 1998, t. 6, nr 11.

Tomas Kulka, Kitsch, „British Journal of Aesthetics” 1988, vol. 28, nr 1.

Dominick LaCapra, History and its Limits: Human, Animal, Violence, Cornell

University Press, New York 2009.

Andrzej B. Legocki, Naukowe definicje życia, „Nauka” 2009, nr 1.

Paul Maltby, Kinkade, Koons, Kitsch, http://www.jcrt.org/archives/12.1/maltby.pdf. Winifred Menninghaus, On the 'Vital Significance' of Kitsch: Walter Benjamin's Politics of 'Bad Taste', [w:] Walter Benjamin and the Architecture of Modernity, red. A. Benjamin, Ch. Rice, Re:press, Melbourne 2009.

Susan Merrill Squier, Liminal Lives. Imagining the Human at the Frontiers of Biomedicine, Duke University Press, North Carolina 2004.

Maria Poprzęcka, O złej sztuce, WAiF, Warszawa 1998.

Signs of life. Bio Art and Beyond, ed. E. Kac, MIT Press, Cambridge 2007.

Eugene Thacker, Biomedia, University of Minnesota Press, Minneapolis 2004.

Eugene Thacker, The Global Genome - Biotechnology, Politics, and Culture, The MIT Press, Cambridge 2005.

The Nature of Life, red. M.A. Bedau, C.E. Cleland, The MIT Press, Cambridge 2010. Steve Tomasula, Genetic Art and the Aesthetics of Biology, „Leonardo” 2002, nr 35. Edward N. Trifonov, Definition of Life: Navigation through Uncertainties, „Journal of Biomolecular Structure and Dynamics" 2012, vol. 29, nr 4.

Stephen Wilson, Information Arts. Intersection of Art, Science, and Technology, The MIT Press, Cambridge 2002.

\section{Life as a Kitsch. Notes about Bio Art}

Bio art is a specific trend of contemporary art practice, where artists adapt solutions offered by biosciences in order to create living works of art. Their actions are a subject to a discussion with dominant voices concerning the significance of such experiments for the fundamental ascertainments concerning what life is, but also for understanding the status of these constructed entities, which thus fur have not existed in nature. Posthumanist 
discourses such as aesthetics of care, non-anthropocentric aesthetics and zoe-aesthetics are a few examples of this type of reflection. However, is it possible that works, which could be described in terms of kitsch, constitute a solid ground for discussion of this kind?

Clement Greenberg has written of kitsch that it is 凶mechanical and operates by formulas. Kitsch is vicarious experience and faked sensations. Kitsch changes according to style, but remains always the same. Kitsch is the epitome of all that is spurious in the life of our times $\mathbb{X}$. If kitsch represents everything that is spurious and non-authentic in our life, can we use it in order to make general statements concerning the basis of life? Can we make statements concerning the fundamental problem of life on the basis of projects, which confront us with glow-in-the-dark rabbits or paintings created with genetically modified colorful bacteria? In my paper I would like to refer to these questions on the basis of an artwork that can be classified in terms of kitsch.

Keywords: kitsch, bio art, life, biotechnology, DNA, fluorescent bunny. 


\section{Wydawnictwo Naukowe UKSW poleca}

\section{Nieuniknione}

Sołomon Bart

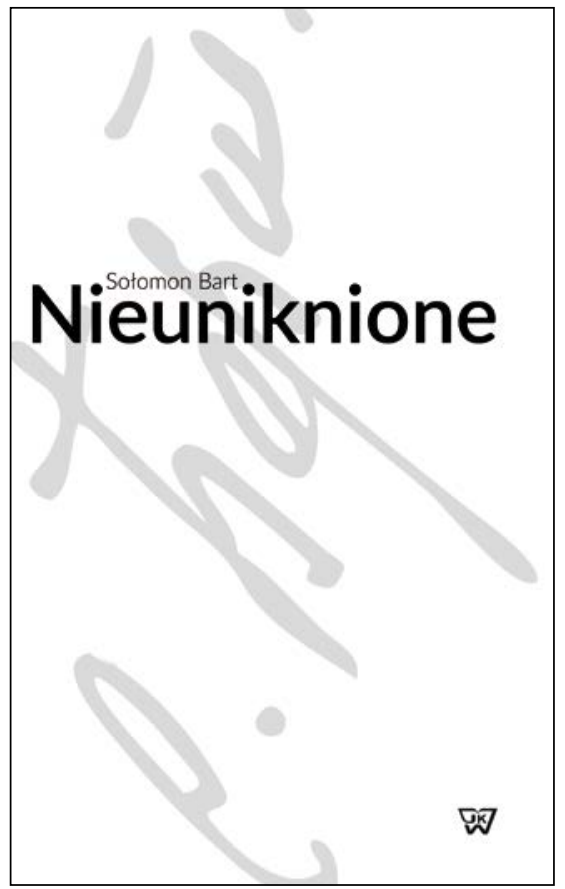

Tom zawiera wybór wierszy Sołomona Barta, rosyjskiego poety, który po ucieczce z ogarniętego rewolucją Petersburga zamieszkał w Warszawie. Tu też zmarł w getcie w 1941 roku. 